\title{
Effect of 6-Month Fascia-Oriented Training on Jump Performance in Elite Female Volleyball Players
}

\section{Vliv šestiměsíčního tréninku fascií na výskok u extraligových volejbalistek}

\author{
Renáta Vychodilová, Martin Zvonař, Martin Sebera
}

Faculty of Sports Studies, Masaryk University, Czech Republic

\begin{abstract}
Presumed on published research findings, the fascia-oriented training can enhance physical performance potential. It is supposable that the employment of the "Catapult Mechanism", the ability of the fascial tissue to store and release kinetic energy, its remodelling, rehydration and release may enable more effective and higher jump performance. The review of research studies and findings further reveal that little applied research has been conducted bringing scientific evidence verifying these findings in sports practice. The current study was conducted to assess the effect of the 6-month, fascia-oriented training programme, designed in accordance with the principles of the fascia-oriented exercise (Fascial Fitness), on the height of the vertical jump in well-trained junior volleyball players. 16 female players (age 17.31 \pm 0.98 ; height 173 \pm 5.26 ; weight $65.25 \pm 6.75$ ), competing in the national league, were randomly assigned for the training (TG) and control group (CG). TG performed a supervised 25-minute fascia-oriented training twice a week for six months. The measurements were conducted before and after the training intervention, and involved the test of the countermovement jump with all arm movements (CMJ); all subjects performed 3 trials. The study hypothesized that the height of jump would increase more significantly in TG than in CG after the intervention. The results show that the height in $T G$ increased comparing to $C G$, though the difference is not statistically significant. The results of the effect size manifest the increase of medium level, by $2.2 \mathrm{~cm}$ in TG. In conclusion we state that the results of the study indicate that the application of the 6-month, fascia-oriented training aimed to develop the vertical jump performance potential in elite volleyball players is not statistically significantly beneficial.
\end{abstract}

\begin{abstract}
Abstrakt
Na základě dosud publikovaných výzkumných zjištění lze předpokládat, že trénink zaměřený na pojivovou tkáň může přinést zkvalitnění pohybového výkonu. Z poznatků Ize usuzovat, že využití tzv. „katapultového mechanismu", schopnosti fasciální tkáně ukládat a uvolňovat kinetickou energii, remodelace její struktury, rehydratace a uvolnění může přinést efektivnější provedení vertikálního výskoku a jeho zvýšení. Z rešerše literatury dále vyplývá, že studií v oblasti aplikovaného výzkumu, které by se touto problematikou zabývaly, a které by ověřovaly účinnost teoretických poznatků z této oblasti ve sportu, nenímnoho. Cílem této studie je posouzení efektu šestiměsíčního intervenčního tréninkového programu navrženého $v$ souladu se zásadami cvičení fascií (Fascial Fitness) na výšku vertikálního výskoku

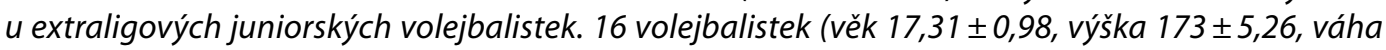
$65,25 \pm 6,75)$, členek extraligového týmu, bylo náhodným výběrem rozděleno do dvou skupin, experimentální (ES) a kontrolní (KS). ES realizovala dvakrát týdně po dobu šesti měsíců 25ti-minutový tréninkový program, orientovaný na fasciální tkáň. Před realizaci intervenčního programu bylo provedeno vstupní měření, po jeho ukončení měření kontrolní. V rámci měření prováděly obě sledované skupiny test vertikálního výskoku s protipohybem (CMJ), participantky měly vždy 3 pokusy. Studie predpokládala, že na základě aplikace intervenčního programu dojde u ES ke statisticky významnějšímu zlepšení výskoku než u KS. Výsledky studie ukazují, že výška výskoku se u ES ve srovnání s KS zvýšila, rozdíl však není statisticky významný. Z výpočtu věcné významnosti rozdílu pomocí Cohenova koeficientu d však vyplývá, že zlepšení u tréninkové skupiny o $2.2 \mathrm{~cm}$ je věcně významné. Závěrem konstatujeme, že aplikace šestiměsičního intervenčního tréninkového programu navrženého v souladu se zásadami cvičení
\end{abstract}


fascií, cíleného na zlepšení potenciálu vertikálního výskoku u extraligových juniorských volejbalistek nebyla prokázána jako statisticky signifikantní.

\section{Keywords: volleyball, fascia-oriented training, jump performance.}

Klíčová slova: volejbal, trénink fascií, výskok.

\section{INTRODUCTION}

Jumping is one of the basic essential skills involved in the game of volleyball. As performed frequently in volleyball, it is advisable to pay attention to its correct and effective performance. The enhancement of the vertical jumping performance may improve the players' and consequently the team's performance, and efficiency. The effective cooperation of many organs and structures is vital in movement. Thus the fascial network, quite overlooked until recently should be taken into consideration too. According to latest research findings, this tissue plays a more important role in movement than assumed before (Schleip, Findley et al., 2012). As sport is about motion, the idea of how to include fascia-oriented training into other training processes is obvious.

Concerning research studies focused on fascia, some authors have dedicated their research to redefine the nomenclature of the connective tissue (Schleip, Jäger et al., 2012), where new definitions of fascia corresponding to new research findings are constantly being proposed. Other researchers examine different physiological processes in fascia, their principles and relations, such as the production of collagen (Schleip, Findley et al., 2012; Gelse et al., 2003), the architectural structure (Stecco et al., 2011), the water phase in fascial structures and its behaviour (Pollack, 2013) and sensory receptors of fascia and proprioception (Kopeinig et al., 2015). Regarding the role of fascia in motion, there are studies dealing with muscle-fascia-tendon interactions, the ability of elastic fascial structures to store and release kinetic energy, the "catapult" or "catch" mechanism and its principles (Astley \& Roberts, 2012; Roberts, 2006; Roberts \& Konow, 2013; Kawakami et al., 2002; Purslow, 2002; Kram \& Dawson, 1998). These research studies first focused on animals, and only later on humans, showed that elastic fascial structures dispose of the ability to store and release kinetic energy highly effectively. Animals, such as frogs, kangaroos and other species jump more powerfully and faster than their muscle limitation enables. In these jumps, muscle contraction loads elastic fascial structures, which then recoil to release the stored energy (Kram \& Dawson, 1998; Astley \& Roberts, 2012; Astley \& Roberts, 2014). Being successfully applied in sport, this mechanism, which humans are also capable of (Fukunaga et al., 2002; Sawicki et al., 2009), might bring a positive effect on various sports performances, including jumping.

Concerning the fascia-oriented training, Schleip \& Müller (2013) claim that fascia is trainable. It undergoes changes in the course of the human life caused by different factors, such as injuries, overloading, stress or aging, and its shape and efficiency worsen. As fascia reacts to strain-loading demands (EI-Labban et al., 1993), a specific training load can also cause both desired and undesired changes in this tissue. Although we unintentionally and naturally train fascia in other types of training, specific fascia-oriented exercise is more effective (Schleip et al., 2015; Schleip \& Müller, 2013). The goals of this training are the mechanical lengthening, architectural remodeling, hydration and release of fascial elements, proprioceptive stimulation, stimulation of fibroblasts and their bio-chemical processes, effective storage and release of kinetic energy in fascial structures (Myers, 2009; Schleip \& Müller, 2013; Schleip et al., 2015). Fascia-oriented training consists of different stretching techniques and self-treatment massages, whose performance should be executed according the specific principles defining the duration, intensity and frequency of the training, the involvement of stretching techniques and the exercise arrangement (Schleip \& Müller, 2013). 
Regarding a possible impact of the fascia-oriented training on the motion performance potential and different movement tasks and skills in sport, we review that this area has not been researched thoroughly yet. A few studies have been done to observe the influence of some separate techniques of the fascia-oriented training system, such as hopping (Lamontagne \& Kennedy, 2013) or foam rolling (Barnes, 1997). Some other studies focus on the impact of the fascia-oriented training on different motion tasks such as running (Holt et al., 2014).

The aim of our study is to examine the effect of fascia-oriented training on jumping performance in volleyball, and thus to apply the latest findings in fascia research into sports practice. Based on our experience with the training of elite female volleyball players, and on our experience of employing the fascia-oriented training system in exercise lectures provided for students at our university, we aimed to assess the effect of fascia-oriented training on the jumping performance in volleyball by measuring the height of the jump. Based on research findings (Schleip, Findley et al., 2012), we presumed that the application of fascia-oriented training would have a positive impact on the height of jump in elite female volleyball players. It might bring a more effective employment of the storage and utilization of the kinetic energy in fascial structures in lower extremities. Additionally, the remodelling, rehydration and refinement of these structures might support the improvement of the jumping performance. If our presumptions verified, the involvement of fascia-oriented training into other training processes might offer a benefit to coaches and athletes not only in volleyball.

\section{METHODS}

\section{Subjects}

Sixteen well-trained female volleyball players (age $17.31 \pm 0.98$ years; height $173 \pm 5.26 \mathrm{~cm}$; weight $65.25 \pm 6.75 \mathrm{~kg}$ ) volunteered to participate in the study. All subjects were members of a female volleyball team who competed in the national league of the Czech Republic. The subjects were assigned to the training (TG) and control group (CG) randomly. All subjects were free of injury at the beginning of the experiment. Two subjects had to be excluded for the health reasons. 14 subjects completed the experiment, seven from the TG and seven from the CG. The research subjects signed the informed consent about voluntarily participating in the research and agreed with the anonymous data analysis.

\section{Design}

This study was a longitudinal training experiment with testing completed before and after the application of the 6-month fascia-oriented training employed twice a week. The information session was held in the beginning. The subjects were explained the aim and requirements of the study. The training programme and testing protocols were introduced, and a fascia-oriented training session was demonstrated.

\section{Fascia-oriented training programme}

The training sessions with the experimental group regularly took place at the end of their volleyball training twice per week (Tuesday and Friday). The programme involved a supervised 25-minute fascia-oriented programme strictly designed in accordance with the principles of the fascia-oriented training (Schleip \& Müller, 2013). Every session consisted of three parts: the self-treatment massage of feet with foot massage balls, the stretching part and the massage of the legs on foam rollers. The foot massage aimed at foot awakening and release took 5 minutes, with 2.5 minutes on each foot. The massage involved methodical slow longitudinal rolling of the foot 
over the ball in the direction of the tendons and ligaments in the sole, the crosswise rolling of the foot arch over the ball, repeated compressions of the ball by the foot and multi-directional slow dynamic stretches of the toes with the ball compressed under the foot arch. The middle part took 10 minutes and focused on elasticity, architectural structure and the catapult mechanism of fascial structures in the lower extremities. This part was divided into two subparts and involved stretching techniques. The first subpart included 6-minute protocols of slow actively-loaded dynamic stretching, where diagonal, sideways, multi-directional movements, undulations and rotations supported with the work of the arms and torso were performed. Different body positions were involved in the course of the intervention to refine proprioception, namely the standing, sitting, kneeling, and forearm-supported lying down position. The other subpart took four minutes and involved 10-30-second periods of rhythmical mini-bouncing stretches in legs performed in their lengthened stretch positions, and hopping. 10-30-second pauses of release or static stretching followed the mini-bouncing periods. The middle part was completed with 5-15 repetitions of fast actively-loaded dynamic stretching, which involved the proximal initiation, pre-tensioning and the involvement of long myofascial chains according to the principles of fascia-oriented training (Schleip \& Müller, 2013; Myers, 2009). The last part aimed at fascial release and rehydration took 10 minutes. It involved a slow self-treatment massage of the lower extremities on foam rollers. The participants rolled the front and back, inner and outer parts of the calves and thighs, and the buttocks over the foam roller longitudinally and multi-directionally in a very slow manner. To release the tightness, the participants stopped the rolling process for several seconds in stiff places. A lecturer experienced in the fascia-oriented training guided all training sessions.

\section{Testing Protocol}

The tests were performed before and after the application of the 6-month, fascia-oriented training. The countermovement jump test was used to measure the jumps; three standing vertical countermovement jumps were performed with all arm movements. To conduct and record the trials, we used the force plate Bertec FP6012-15-4000 operating at a sampling frequency of $360 \mathrm{~Hz}$. The synchronous 3D kinematic analysis Simi Motion version 9.0.5 recorded and analysed the height of the jumps. The markers placed on the right and left iliac crests recorded the execution of the jumps. To eliminate deviations in the differences between the right and left side, the height of the jumps was recorded as a virtual point. The centre of abscissa between markers located on the left and right iliac crests represented the virtual point. The perpendicular distance of the virtual point along the plane $\mathrm{Z}$ towards the planes $\mathrm{XY}$ was calculated as the height. When conducting the jumps, the subjects were encouraged to perform each trial with maximum effort to reach as high as possible. The 20 -second rest followed each jump. The highest trials were used for the subsequent statistical analysis.

\section{Statistical Analyses}

The results were statistically analysed by the Statistics 12, Statsoft. To verify the existence of normal data distribution ( $p>0.05$ ), Kolmogorov-Smirnov and Shapiro-Wilks statistical tests were executed first. Then, the paired-sample $t$-test was carried out to determine the statistical significance, with a criterion of alpha level of $p<0.05$. The highest trials of all participants of the experimental and control group were used for the statistical tests. The method of Cohen $d$ was used to assess the size of the effect. 


\section{Results}

The results of the current study are presented in Tables 1-4. The basic values of measurements of TG and CG are illustrated in Figure 1.

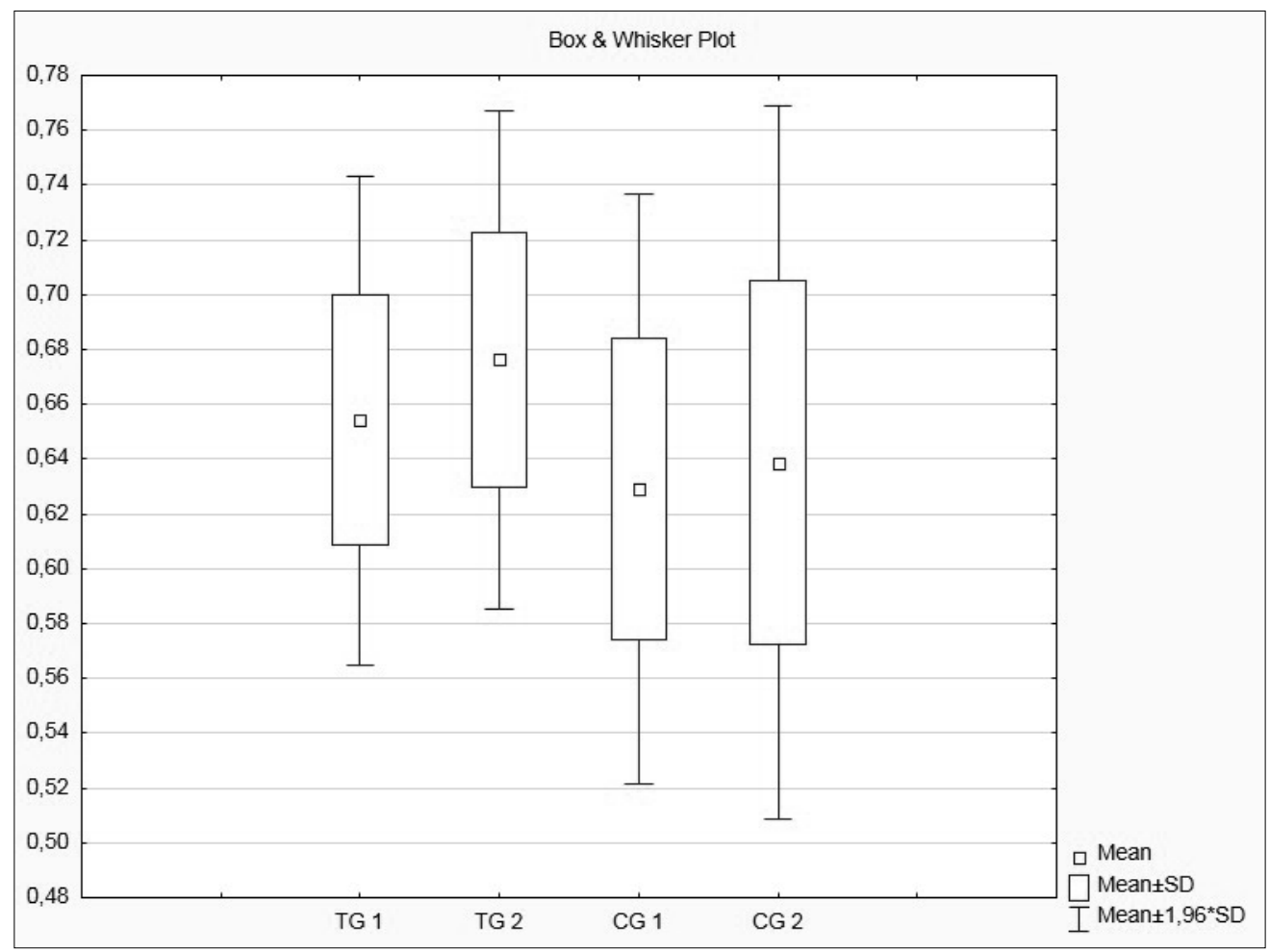

Fig. 1: Basic values of measurements of TG and CG

Tab. 1 depicts the mean and standard deviation of both groups in both measurements. We did not reject the hypothesis about normality of data, as shown in Table 2.

Tab. 1: Basic statistical characteristics

\begin{tabular}{|c|c|c|c|c|c|c|}
\hline Group & Valid N & $\begin{array}{c}\text { Mean } \\
\text { (metres) }\end{array}$ & $\begin{array}{c}\text { Median } \\
\text { (metres) }\end{array}$ & $\begin{array}{c}\text { Std. Dev. } \\
\text { (metres) }\end{array}$ & $\begin{array}{c}\text { Confidence SD } \\
\mathbf{- 9 5 . 0 0 0 \%}\end{array}$ & $\begin{array}{c}\text { Confidence SD } \\
\mathbf{+ 9 5 . 0 0 0 \%}\end{array}$ \\
\hline TG 1 & 7 & 0.6541 & 0.6620 & 0.0456 & 0.02936 & 0.1003 \\
\hline TG 2 & 7 & 0.6763 & 0.6788 & 0.0465 & 0.02996 & 0.1024 \\
\hline CG 1 & 7 & 0.6292 & 0.6260 & 0.0550 & 0.03543 & 0.1211 \\
\hline CG 2 & 7 & 0.6388 & 0.6594 & 0.0664 & 0.04279 & 0.1462 \\
\hline
\end{tabular}

Tab. 2: Test of normality distribution

\begin{tabular}{|c|c|c|c|c|c|c|}
\hline Group & N & max D & K-S p & Lilliefors p & W & p \\
\hline TG 1 & 7 & 0.1936 & $\mathrm{p}>.20$ & $\mathrm{p}>.20$ & 0.9142 & 0.4257 \\
\hline TG 2 & 7 & 0.1706 & $\mathrm{p}>.20$ & $\mathrm{p}>.20$ & 0.9419 & 0.6559 \\
\hline CG 1 & 7 & 0.1228 & $\mathrm{p}>.20$ & $\mathrm{p}>.20$ & 0.9913 & 0.9953 \\
\hline CG 2 & 7 & 0.2192 & $\mathrm{p}>.20$ & $\mathrm{p}>.20$ & 0.8881 & 0.2649 \\
\hline
\end{tabular}

Note: $D=$ value of Kolmogorov-Smirnov statistics, $K-S p=$ probability of Kolmogorov-Smirnov test, Lilliefors $p=$ probability of this test, $W=$ value of Shapiro-Wilk statistics, $p=$ probability of Shapiro-Wilk test 
Regarding statistical significance, the paired-sample $t$-test determined that the effect of the fasciaoriented training programme on the height of jump is not statistically significant in the training group, as shown in Table 3. As the results of the statistical analysis determine, the increase of the jump by 2.2 centimetres in the training group is not statistically significant, but the size effect (Cohen $\mathrm{d}$ ) indicates the effect of the training programme in the training group as being of middle significance. In the control group, the height of the jump increased by 0.9 centimetres. This difference is neither statistically nor substantively significant. The difference between the training and control group in the first measurement was not statistically significant (Table 4). In the second measurement, the difference was not statistically significant either. However, according to the results of the effect size, the difference increased, so we can confirm a positive effect in favour of the training group.

Tab. 3: Paired-sample T-test, training and control groups between measurements 1 and 2

\begin{tabular}{|l|c|c|c|c|c|c|}
\hline Group & Diff. (metres) & Std.Dv. Diff. & T & df & p & Cohen d \\
\hline TG 1-TG 2 & -0.0221 & 0.0540 & -1.0835 & 6 & 0.3202 & -0.4469 \\
\hline CG 1-CG 2 & -0.0096 & 0.0433 & -0.5849 & 6 & 0.5799 & -0.1461 \\
\hline
\end{tabular}

Note: Diff = difference between measurements, Std. Dv. Diff., $T=$ value of $T$ statistics, $d f=$ degree of freedom, $p=$ probability

Tab. 4: Paired-sample T-test, training vs. control groups in measurements 1 and 2

\begin{tabular}{|c|c|c|c|c|}
\hline Measurement & t-value & df & p & Cohen d \\
\hline 1 & 0.9236 & 12 & 0.3739 & 0.4584 \\
\hline 2 & 1.2230 & 12 & 0.2448 & 0.6084 \\
\hline
\end{tabular}

Note: $T$-value $=$ value of $T$ statistics, $d f=$ degree of freedom, $p=$ probability of $t$-test

\section{DISCUSSION}

According to current knowledge (Schleip et al., 2015; Schleip, Findley et al., 2012; Schleip et al., 2005; Kawakami et al., 2002), we expected that the fascia-oriented training applied systematically during six months would induce an increase of the jump height in the training group. As the results of the study suggest, the application of the 6-month fascia-oriented training did not significantly increase the value of the observed parameter, and thus it does not seem to be effective for increasing the jump performance in well-trained, national level, youth volleyball players. On the other hand, the effect size indicates a medium level of significance. This finding should be taken into account when analysing the results.

Based on the results of the study supported with current research findings, we infer that there could be several reasons for the lack of significant impact. First, a longer duration of the training programme than set in our current study might bring more significant changes. As among the fascia-oriented training principles, there is a recommendation of the minimum-maximum length of 6-24 months during which the training starts to induce desired changes in the tissue that the method focuses on, such as collagen production, elastic recoil, and architectural remodelling (Schleip et al., 2015).

Second, there is no standard, designed system of programmes with sets or sequences of particular stretching techniques and exercises elaborated in detail. When setting up the contents of the training programme, we took into consideration the specific needs of volleyball training in jumping performances and our goal, as well as the fascia-oriented exercise principles, our knowledge and our experience with this training method. We suppose that further studies elaborating and 
examining the design of such programmes should be conducted in order to get into expert perspectives. We assume that they could bring intelligent, effective, profitable and beneficial programmes generally usable to enhance jumping performances and efficiency in different areas of sport.

Next, a small number of observed subjects determined by our research goal could be another factor limiting the study. The players' training history is another element that might have played its role. Before the experiment was conducted, the subjects had had an individual training history, where their jumping skills vital for the game of volleyball had been trained and developed. The time the players trained in the current team differed. As noted in their team training records, some started their volleyball carrier in the smaller towns where they lived and joined the team at the age 12-15.

Additionally, we suppose that motivation is an extremely important prerequisite influencing the effect of the training programme. At the end of the training season, the team suffered from the loss of motivation. Although the team participated in the national league competition, the majority of its members had to study for their "Maturita" (school leaving) exams and some of them already knew that their sports carrier was coming to its end. These factors weakened their motivation and training morals, and reflected on their determination to perform the fascia-oriented programme.

Finally, the impact of genetics should be mentioned. There are many non-genetic factors influencing fascial tissues. Many of these are primarily conditioned by genetic predispositions anyway (Foster, 2012). The determination of genetic factors is a complex problem whose analysis was not the aim of this study. Nevertheless, research on potential genetic aspects relevant to physical performance in connection with the properties of fascial tissues could bring a better understanding to this field.

\section{CONCLUSIONS}

In conclusion, the results of the current study showed that the 6-month, fascia-oriented training programme did not produce significant changes in the vertical jump test applied. The findings of the current study did not positively support the assumption that fascia-oriented training applied as a complementary tool of volleyball training in well-trained female volleyball players can be effective and bring an improvement in jumping skills. As the examined group of our study was small, we suggest including more participants when conducting future applied research. Based on literature review, we can conclude that little research has been done so far dealing with the impact of this training method applied for longer time, and focused on sports performance, efficiency, or on different motion tasks. Therefore, we suggest aiming future research studies at longer applications of the fascia-oriented training. We further propose that future research should examine and assess the possible impact of the practical application of this specific training method on injury prevention in sport.

\section{Acknowledgment}

The study has been supported by the research grant from the Ministry of Education, Youth and Sports of the Czech Republic (ROZV/20/FSpS/12/2015, ID=31314) "The Effect of the FasciaOriented Training Programme on the Development of Jumping Skills in Elite Female Volleyball Players". Research was conducted in accordance with ethical principles, and was approved by the Ethical Committee of the Faculty of Sports Studies, Masaryk University, Brno, in March 2015. 


\section{References}

Astley, H. C., \& Roberts, T. J. (2014). The mechanics of elastic loading and recoil in anuran jumping. Journal of Experimental Biology, 217(24), 4372-4378.

Astley, H. C., \& Roberts. T. J. (2012). Evidence for a vertebrate catapult: elastic energy storage in the plantaris tendon during frog jumping. Biology letters, 8(3), 386-389.

Barnes, M. F. (1997). The basic science on myofascial release: morphologic change in connective tissue. Journal of Bodywork and Movement Therapies, 1(4), 231-238.

El-Labban, N. G., Hopper, C., \& Barber, P. (1993). Ultrastructural finding of vascular degeneration in myositis ossificans circumscripta (fibrodysplasia ossificans). Journal of Oral Pathology and Medicine, 22(9), 428-431.

Fukunaga, T., Kawakami, Y., Kubo, K., et al. (2002). Muscle and tendon interaction during human movements. Exercise and Sport Sciences Reviews, 30(3), 106-110.

Foster, B. P., Morse, C. I., Onambele, G. L., Ahmetov, I. I., \& Williams, A. G. (2012). Genetic variation, protein composition and potential influences on tendon properties in humans. The Open Sports Medicine Journal, 6(1), 8-21.

Gelse, K., Pöschl, E., \& Aigner, T. (2003). Collagens—structure, function, and biosynthesis. Advanced Drug Delivery Reviews, 55(12), 1531-1546.

Holt, N. C., Roberts, T. J., \& Askew, G. N. (2014). The energetic benefits of tendon springs in running: is the reduction of muscle work important? Journal of Experimental Biology, 217(24), 4365-4371.

Kawakami, Y., Muraoka, T., Ito, S., Kanehisa, H. \& Fukunaga, T. (2002). In vivo muscle fibre behavoural during countermovement exercise in human reveals a significant role for tendon elasticity. The Journal of Physiology, 540(2), 635-646.

Kopeinig, C., Gödl-Purrer, B., \& Salchinger, B. (2015). Fascia as a proprioceptive organ and its role in chronic pain - a review of current literature. Safety in Health, 1(Suppl 1), A2.

Kram, R., \& Dawson, T. J. (1998). Energetics and biomechanics of locomotion by red kangaroos (Macropus rufus). Comparative Biochemistry and Physiology - Part B: Biochemistry and Molecular Biology, 120(1), 41-49.

Lamontagne, M., \& Kennedy, M. J. (2013). The biomechanics of vertical hopping: a review. Research in Sports Medicine, 21(4), 380-394.

Myers, T. W. (2009). Anatomy trains: Myofascial meridians for manual and movement therapists. Amsterdam: Elsevier Limited. ISBN 978-0-443-10283-7.

Pollack, G. H. (2013). The fourth phase of water: a role in fascia? Journal of bodywork and movement therapies, 17(4), 510-511.

Purslow, P. P. (2002). The structure and functional significance of variations in the connective tissue within muscle. Comparative Biochemistry and Physiology - Part A: Molecular and Integrative Physiology, 133(4), 947-966.

Roberts, T. J. (2006). Integrated muscle-tendon function during running accelerations. Journal of Biomechanics, 39(Suppl 1), $\mathrm{S} 360$.

Roberts, T. J., \& Konow, N. (2013). How tendons buffer energy dissipation by muscle. Exercise and Sport Sciences Reviews, 41(4), 186-193.

Sawicki, G. S., Lewis, C. L., \& Ferris, D. P. (2009). It pays to have a spring in your step. Exercise and Sport Sciences Reviews, 37(3), 130-138

Schleip, R., Avison, J., Chaitow, L., Denenmoser, S., Eddy, D. et al. (2015). Fascia in Sport and Movement. Edinburgh: Handspring Publishing. ISBN 978-1-909141-07-0.

Schleip, R., \& Müller, D. G. (2013). Training principles for fascial connective tissues: scientific foundation and suggested practical applications. Journal of Bodywork and Movement Therapies, 17(1), 103-115.

Schleip, R., Findley, T., Chaitow, L., \& Huijing, P. (Eds.) (2012). Fascia: The Tensional Network of the Human Body: The science and clinical applications in manual and movement therapy. Churchill Livingstone: Elsevier. ISBN 978-0-7020-3425-1.

Schleip, R., Jäger, H., \& Klingler, W. (2012). What is 'fascia'? A review of different nomenclatures. Journal of Bodywork and Movement Therapies, 16(4), 496-502.

Schleip, R., Klingler, W., \& Lehmann-Horn, F. (2005). Active fascial contractility: Fascia may be able to actively contract in a smooth muscle-like manner and thereby influence musculoskeletal dynamics. Medical Hypotheses, 65(2), $273-277$.

Stecco, C., Macchi, V., Porzionato, A., Duparc, F., \& De Caro, R. (2011). The fascia: the forgotten structure. Italian Journal of Anatomy and Embryology, 116(3), 127-138. 